NOVA

University of Newcastle Research Online

nova.newcastle.edu.au

Leahy, Terry; Bowden, Vanessa; Threadgold, Steven "Stumbling towards collapse:

coming to terms with the climate crisis" Environmental Politics Vol. 19, Issue 6, p. 851-868 (2010)

Available from: http://dx.doi.org/10.1080/09644016.2010.518676

This is an Accepted Manuscript of an article published in Environmental Politics on 20/10/2010, available online:

http://www.tandfonline.com/10.1080/09644016.2010.518676

Accessed from: http://hdl.handle.net/1959.13/926601 


\title{
Stumbling towards collapse: coming to terms with the climate crisis
}

Terry Leahy ${ }^{\mathrm{a}}$; Vanessa Bowden ${ }^{\mathrm{a}}$; Steven Threadgold ${ }^{\mathrm{a}}$

${ }^{\text {a }}$ School of Humanities and Social Sciences, University of Newcastle, Australia

Corresponding author: Terry.Leahy@newcastle.edu.au

Terry Leahy, School of Humanities and Social Sciences, University of Newcastle, University Drive, Callaghan, NSW, 2308, Australia

\begin{abstract}
Leading sociologists have approached the climate crisis by emphasizing a way forward and identifying hopeful directions. What sense is to be made of suggestions that we are instead on the brink of a 'collapse' in which the crisis is not resolved but leads to the end of existing civilisation? Partly based in three studies of contemporary opinion in the Hunter Valley in Australia, a coal industry centre, this discussion is also based in an examination of the public response to climate change world wide, the nature of the crisis as understood by science, the political response so far and the economic problems of replacing fossil fuels. What social theories might help explain what is happening? It is concluded that 'collapse' can be understood by conceiving capitalist society as a social machine, informed by a 'social imaginary'.
\end{abstract}

Key words: Climate change; Hunter Valley; collapse; capitalism; social imaginary 



\section{Introduction}

In 2008, Constance Lever-Tracy argued that, despite public concern and political contestations (Rootes 2008), within sociology, environmental issues and global warming are far from the mainstream. Yet in 2009, three major works of sociology were published on these topics.

Anthony Giddens (2009) applies social science to develop feasible political solutions. Working within parliamentary democracy, he favours state regulation and taxes - rather than trading systems - combined with government investment in renewable energy. As with writers such as Amory Lovins, David Suzuki and the 'ecological modernization' school (Mol and Spaargaren 2000), Giddens believes that measures to combat climate change can create opportunities for business and does not envisage a basic change that would end capitalism.

Ulrich Beck (2009) has more sense of the enormity of the changes necessary to rein in climate change, arguing that the move to 'world risk society' from the 'first modernity' is so fundamental as to amount to a change in the mode of production. The environmental risks created by business threaten to rebound upon those who hoped to benefit by creating the risks in the first place - the 'boomerang effect'. Beck argues that a newly strengthened cosmopolitan public sphere will have the power to reject technological change that risks environmental damage. Globalized capital will be disempowered 'because the consequences of investment decisions give rise to global risks, destabilize markets and awaken the power of the sleeping consumer giant' (Beck 2009, p. 66). There will be democratic control of the processes of production on a global scale. To reign in climate change, governments in rich developed countries will have to bow to pressures from developing countries.

Like Giddens, Beck remains 'realistic' in so far as he envisages a largely peaceful process of political reform in which the business elite (mostly) adapts to the requirements of a new sustainable economy.

The broader social science literature on climate change echoes the perspective that dealing with the problem is inevitable, and that the task is to find solutions to the problem that fit within current governance and moral structures (Beckman and Page 2008, Caney 2008, Kamminga 2008, Page 2008, van der Heijden 2008). At the centre of this debate are issues of social and intergenerational justice and morality. Political strategists propose 'pragmatic' solutions - governments must introduce unpopular policies early in their term of office, or negotiate away their right to decide on 'less important' policies (Compston 2008). Layfield (2008) and Grundig (2009) promote social movements that will influence government policy.

All offer valuable insights and presume that the population and political and economic elites understand the nature of the crisis and respond rationally. They do not envisage that they might deny the real nature of the crisis or refuse to act appropriately (Hamilton 2010).

Dennis and Urry (2009) consider much more negative outcomes. One of their three possible scenarios is 'Regional Warlordism', in which there are 'sharply declining physical amenities and erosion of the social and moral underpinnings of civilization' (Dennis and Urry 2009, p. 151, Cf. Urry 2008, 2010). A quite possible future path for global society is what Diamond (2005), following Tainter (1988), referred to as a 'collapse'. Diamond argues that a number of past civilisations (including the Mayans, Easter Island, the Anasazi) collapsed as a result of their inability to deal with environmental problems they created. A collapse is something 
quite particular - wars and civil conflict, famine, population crash, massacres of the ruling class - followed by centuries in which large scale state control collapses and much smaller political units - egalitarian bands, small communes, warlords dominate.

Of course, these are not the only sociological engagements with climate change, sustainability and environment. There is a long lineage of analysis within a Marxist framework (Pepper 1993, O’Connor 1999, Foster 2000, Kovel 2007), and the journal Capitalism, Socialism, Nature (Cf. Special Issue on 'Capitalism and Climate Change', Change and Development, 2009). We suggest that the favoured solution posed in this literature - a global socialist revolution - seems unlikely. We will argue that a more likely outcome is collapse, and will attempt to explain why.

In what follows, we will briefly outline the nature of our predicament and the difficulties of transition to sustainability, before discussing the political response and the public mood to ground discussion of our own qualitative data that illustrates the 'two-track thinking' of the public alongside the predictable denial of 'business leaders'. We conclude with suggestions for theoretical understandings of the social dynamics of collapse.

\section{The nature of our predicament}

One of the founding arguments for collapse, along with the prediction of peak oil, is the science of global warming. While the science is presented here in a way that focuses on the policy debate, we are aware of the complexity of climate science, the difficulty of attaining certainty and the way versions of the science are assembled from a variety of disparate disciplinary perspectives, ranging from climate science to biology to palaeontology (Maslin 2009; Urry 2005, see also Special Issue on 'Changing Climates', Theory, Culture and Society 2010). Our view is that, contrary to accusations that the IPCC has exaggerated the science of climate change, other scientific analyses and recent data suggests the problem may have been underestimated.

A key argument is that even the 0.5-degree increase that we have had so far was enough to start the melting of polar ice, the disintegration of the Greenland ice cap and the melting of much Antarctic ice. Likely consequences of the current melting are a disastrous rise in sea levels (Spratt and Sutton 2008, p. 70). We have an increase of carbon dioxide in the atmosphere from 280 parts per million in pre-industrial times to 380 parts per million, gradually pushing the global temperature up. Three million years ago when carbon dioxide was at $350-450 \mathrm{ppm}$, seas were 25 metres higher (Spratt and Sutton 2008, p. 37, Hansen et al. 2008). The implication is that we are tracking towards such a rise now.

IPCC forecasts avoid the inclusion of 'slow feedbacks' because models 'differ considerably in their estimates of the strength of different feedbacks in the climate system, particularly cloud feedbacks, oceanic heat uptake and carbon cycle feedbacks' (IPCC 2007, p 67; see also p.73). Yet Hansen and other scientists argue that the palaeoclimate data gives good reason to think these feedbacks are important. A possible feedback is thawing of the Arctic permafrost, releasing a volume of carbon now locked into frozen soils that dwarfs global oil reserves. Under this scenario a rise of six degrees or more is possible - wiping $90 \%$ of species off the earth, as happened 55 million years ago (Spratt and Sutton 2007, p. 108; Hansen et al 2008). 
In addition to sea rises that would destroy coastal cities, the primary drivers of chaos are the effects of drought and deforestation on agriculture (IPCC 2007). Dyer (2008) relates these consequences to their likely social effects in mass starvation, migration and war. These very plausible scenarios are the conditions of collapse (see also Kunstler 2005, Atkinson 2007, Dennis and Urry 2009).

Scientific research is also used to establish policies that would have to be implemented to forestall these disastrous consequences. In the IPCC recommendations, to avoid more than a 2.4 degree rise in temperature, global CO2 emissions need by 2050 to be cut by between 50\% and 85\% from 2000 levels, with a goal of 350 to 400 parts per million of CO2 in the atmosphere (IPCC 2007, p. 67). Hansen argues that a safer goal is to return to less than 350 parts per million as soon as possible to avoid dangerous tipping points (Hansen et al. 2008). Accordingly, a safe aim is often regarded as emission cuts of 90 to 100 per cent (Spratt and Sutton 2007).

\section{The difficulties of transition}

A number of authors have outlined the economic difficulties of moving to anything close to an $85 \%$ cut in carbon dioxide emissions by 2050 . Hamilton argues that to meet that goal, emissions in rich countries would have to fall by 6 to $7 \%$ per annum after peaking in 2020. Yet the fall in emissions following the Soviet collapse was just $5.2 \%$ per annum and that was associated with a halving of GDP in the decade (Hamilton 2010, p. 20). Li (2009) calculates that to achieve a rate of construction of solar and wind power sufficient to ensure some growth and also meet fossil fuel reduction targets, would require construction of 800 giga-watts of alternative energy capacity every year from 2005 to 2050. Over 45 years the total investment would cost US\$126 trillion, not including the costs of the grids and electrifying the whole economy. The annual cost globally would be US\$2.8 trillion. The US share of this would represent a tax on business of half their current profits (Li 2009, pp. 10471954). Trainer (2007, p. 34, 47) argues that renewable energy is massively more expensive per unit of energy than fossil fuels; ten or more times as expensive when storage is taken into account. MacKay (2009) is somewhat more optimistic but includes nuclear power as a possible answer for the transition to renewable energy, a solution that creates a further catalogue of problems including the NIMBY risk politics of waste, the risks of meltdown, terrorism and proliferation of nuclear weapons, and longterm storage of waste (Lowe 2007, Caldicott 2006). Finally, peak oil writers emphasize the rapidity with which a transition would be necessary to avoid collapse after the oil price begins to soar. They see no signs that this is either likely or possible (Heinberg 2003, Kunstler 2005, Pfeiffer 2006). The mild social democratic reformism proposed by Giddens and others is unlikely to be effective in producing the huge economic changes and transfer of energy infrastructure to developing countries that would be required to avoid a collapse.

\section{The political response so far}

We can compare political realities with what the IPCC recommends. Even if we set the goal at what the IPCC considers the minimum safe level, we are looking at a reduction of at least 50\% from 2000 levels by 2050 (IPCC 2007, p. 67). This would be a reduction from 30 gigatonnes per year to 15 gigatonnes per year (IPCC 2007, p. 
66). With 30 gigatonnes and 6 billion people, global average emissions per person were 5 tonnes in 2000. But, in 2050 it is predicted that the global population will be 9 billion. Average per capita $\mathrm{CO}_{2}$ emissions by 2050 would have to be 1.66 tonnes, only $7 \%$ of the current US per capita consumption (figures from Giddens 2009, pp 183189; see also Trainer 2007). It is this sort of calculation that implies that rich countries would have to cut beyond $80 \%$ by 2050 to reach even the minimal 50\% global target, with the implication that cuts of $40 \%$ for rich countries by 2020 would be necessary to make this feasible.

While cuts to this extent are definitely on the political agenda, developments so far do not engender confidence. The Kyoto protocol aimed to cut emissions by 5\% from 1990 levels by 2012, but many signatory nations are unlikely to meet their targets (Giddens 2009, p. 189). Hopes that a replacement for the Kyoto Protocol would be negotiated at the 2009 Copenhagen conference were dashed. What was possible at Copenhagen was undoubtedly constrained by the US position. The US House of Representatives in June 2009 agreed that the US ahould reduce emissions by $17 \%$ by 2020. But this figure is based on 2005 levels - meaning there would be only a 0 to 3\% reduction from 1990 levels (Romm 2009). Thus before Copenhagen, the USA was locked into a minimal target for the next 11 years, making it impossible to agree on a global goal above that. Instead various countries indicated their intentions to continue with the reduction targets that they had already decided upon. China offered to reduce the carbon intensity of its economy by $40 \%$ to $45 \%$ by 2020 , but this would mean only that their carbon dioxide emissions, already $20 \%$ of the global total, would increase by 1.75 to 1.91 times by 2020 rather than the 3.18 times in a business as usual scenario (Levi 2009). As Rogelj, Meinshausen et al. observe (2010: 1126), the combined pledges of governments at Copenhagen imply a greater than $50 \%$ chance that warming will exceed three degrees by 2100 . The promise of a fund of $\$ 100$ billion per annum to be mobilized by 2020 to help the developing world adapt to and mitigate climate change (UNFCC 2009) is far from what would be needed to establish development without fossil fuels (Li 2009).

So what is the point of these minimalist gestures? Blüdhorn (2007) argues that the public calls for these tokens of serious commitment but neither expects nor desires effective action. During this whole period of political inertia, global emissions have been steadily growing. Between 2000 and 2004 they grew by 3.2\% per annum (Raupach et al. 2007), a rate that would double emissions every 23 years (Trainer 2007).

\section{The public mood}

Following a peak of concern about climate change in the media, there has been a strong public campaign to cast doubt on climate science (McCright and Dunlap 2010) and popular feeling is ambivalent.

Norgaard (2006) tries to explain the weakness of public pressure. Studying a Norwegian town, she discovered a 'socially organized denial' (Cf. Hamilton 2010, pp. 95-133). By this, she does not mean that people literally deny climate change. For example they referred to climate change to explain the late ski season. Yet it was rarely a topic of conversation - people 'lived their lives as though they did not know or care about it' (Norgaard 2006, p. 352). Survey data in the UK, the USA and Australia fits with this. While there are solid majorities that maintain that climate change is real and that governments should do something about it, there are sizeable 
minorities who think the problem may be exaggerated and are not sure whether climate change is caused by human action. Those who think it is the most urgent and important problem are always a very small section of the population. People's willingness to pay is far from what is necessary to actually make the huge changes in energy provision and transport infrastructure that could be effective.

Giddens (2009) reports a UK survey from 2008. MORI found that while 30\% were very concerned, only $7 \%$ of respondents put climate change as the main worry facing the country. Only 7\% strongly disagreed with the statement 'I sometimes think climate change may not be as bad as people say' while $42 \%$ agreed or strongly agreed. Almost $60 \%$ thought the government was using climate change to raise taxes. A high proportion agreed that the UK should wait until bigger countries did something (Giddens 2009, pp. 101-103). Spence et al. (2010) discuss a 2010 MORI poll. $72 \%$ were concerned or very concerned about climate change, down from $82 \%$ in 2005 , yet $18 \%$ believed climate change was caused mainly or entirely by natural causes. $40 \%$ agreed that the seriousness of climate change is exaggerated, with $42 \%$ disagreeing. $52 \%$ were prepared to pay up to an extra $£ 10$ on energy bills to ensure their electricity comes from renewable sources, and the other $48 \%$ were not prepared to pay even this minimal amount.

Krosnick's 2010 US survey showed that 74\% believed that climate change was probably happening. Yet 25\% said that, if it was happening, it was due to natural causes. So a politically very significant minority do not believe it is happening, or do not believe it is caused by human activities. A strong majority (76\%) believed that the government should legislate to prevent businesses from emitting greenhouse gases, yet $78 \%$ opposed any increase in electricity prices and $71 \%$ opposed any increase in taxes on gasoline. Instead they favoured tax breaks for companies that reduced emissions (Krosnick 2010)! Garrett and Jackman (2009, p. 7) found that, to mitigate climate change, only $29 \%$ of Americans were actually willing to pay up to US\$129 per year, less than 0.001 per cent of GDP in aggregate. In 2009, the Gallup survey found $41 \%$ believed the seriousness of the problem was exaggerated (Saad 2009). The percentage of Americans surveyed in Gallup polls (between 1989 and 2009) who personally worried about the problem either 'a great deal' or 'a fair amount' varied from a low of 50\% in 1998, to a high of 72\% in 2000, with 60\% in 2009 (Saad 2009). The constant is that a large minority are not overly concerned.

In Australia, the Lowy survey found that in 2009, 48\% agreed that 'Global warming is a serious and pressing problem. We should begin taking steps now even if this involves significant costs', down from 60\% in 2008 and 68\% in 2006 (Hanson 2009, p. 12). Those who put the environment as the most important election issue are small minority - only 8\% in 2007, down from 11\% in 1990 (Pietsch and McAllister 2010, p. 224). Nevertheless, their 2008 ANU poll also reports that a majority of respondents were prepared to pay 'much more' for environmental protection (pp. 224229). It is difficult to assess the quantitative meaning of this declaration.

These examples serve to illustrate the extent of public ambivalence about climate change. We do not want to deny that there is a solid majority who think climate change is real, but what this means politically is another matter, as our own research suggests.

\section{Two-track thinking in the Hunter Valley}


The softness of public support for measures on climate change is clearly important. Our qualitative research and survey data suggests a more complex phenomenon that also fits with Norgaard's analysis (2006). We describe this as 'two-track' thinking: there is one track in which the critical nature of environmental problems is acknowledged, within which people see the future as apocalyptic, and another in which people envisage their own personal future and make decisions about political action, 'business as usual' reigns and there is no acknowledgement of the environmental crisis. Hamilton speaks of this phenomenon as 'distraction', an 'everyday form of denial'. For example, we may switch off the news if the topic is too disturbing, simultaneously believing that our own future will be rosy while the world is in peril (Hamilton 2010, pp. 122,131). This resonates with the sociopsychological literature concerning dissonance, ambivalence and climate change (Stoll-Kleeman, O’Riordan and Jaeger 2001, Carolan 2010, Walker and Shove 2007, Cohen 2010). Our data can also be seen as supporting the theory of individual and societal self-deception elaborated by Blüdhorn (2007, Cf. Hughes 2007) and others. Our interviewees know about the environmental crisis on one track of their thinking but ignore it on the other.

The Australian economy is heavily reliant on the coal industry and the export of coal, particularly to China. The Rudd Labor government promised to double coal exports while maintaining that climate change is the great moral challenge of our time (Curran, 2009). Critics argue that Australian governments suffer from 'quarry vision' where, through lobbying, political donations and favours, the coal industry has similar influence over government as 'Big Oil' does in the US. Pearse (2009) argues that the Australian government is blinded by this influence, propping up 'last century's technology' at the expense of innovation and renewables. The data presented here is derived from Australia's Hunter Valley, a region whose economy is concentrated around coal and Newcastle, one of the world's largest coal export ports (Newcastle Port Corporation 2010). Accordingly, we acknowledge that our data is limited by its specificity and is therefore not necessarily representative of Australia as a whole.

Between 1997 and 2000 Leahy researched environmental attitudes in the Hunter region (Leahy 2003, Gow and Leahy 2005). 36 in-depth interviews and 28 focus groups included a diversity of class positions and age. Questions concerned interviewees' views about environmental problems and the appropriate political response to them. Interviews were taped, transcribed and analysed to identify themes. Most people interviewed had a strong view that environmental apocalypse was just round the corner, combined with an unwillingness to do anything to change that scenario by political action.

This qualitative study was followed by a 2003 phone survey of 300 residents (Gow and Leahy 2005). Interviewees were asked whether they thought any of eight different scenarios of apocalypse might happen. Only 8\% perceived none as likely and the modal response was that four scenarios were likely or very likely: nuclear war, the disintegration of moral values and social order, an environmental collapse or plague. Concern about the environment was expressed in $83 \%$ agreeing to the statement 'Urgent environmental action is needed or the earth would no longer support human life'. Huge majorities were concerned or very concerned about a range of environmental issues. Yet at the same time, this extreme concern was not matched by any willingness to be involved in environmental politics. $72 \%$ never engaged in a local environmental project, even something as politically neutral as a tree planting, 86\% never engaged in any kind of political action, and 98\% were never involved in party politics. This was not because interviewees believed that governments and big 
business were handling environmental issues: $81 \%$ believed the environment was getting worse because too little was being done to protect it; $77 \%$ said the government was doing too little and $73 \%$ said we could not trust elected representatives to protect the environment.

One might have expected that this mismatch would have shifted with more on climate change in the media. However recent research suggests this is not the case. Threadgold (2009) carried out research into students' views of their own futures in three high schools in the Hunter region from 2004 to 2006. One was a working class public school, the second an academically selective public school with mostly middle class parents, and the third a private elite school. A total of 380 students completed a questionnaire and there were nine focus groups - three in each school. Comments written on the surveys provide some extra qualitative data. Most analysis of the data revolved around class influences but several questions evoked responses about the environmental crisis. The relation between these responses and those about personal plans for the future is telling.

Many young people in the study cared passionately about the environment and climate change, largely regardless of social class or gender. Virtually all the focus group participants held quite apocalyptic views of the future in terms of climate change, peak oil, politics and terrorism and war.

Interviewer: So let's talk about the environment specifically, what is going to happen with it?

Laura: [makes an explosion sound] It's going to go down hill and we are going to be living in little bubble bio-spheres!

Andy: The annoying thing is that we have the technology and ability to make everything green; it’s just not economically [sarcastically, making quote marks sign] 'efficient'.

Another noted some environmental problems that might impact in the next 20 years:

Tony: I think it is a lot better for us, but it is gonna get worse. Like, we are already running out of oil and could run out in the next 20 years ... It's good for us now and we're happy to use all the resources. I think 'footprints' are only gonna get bigger because all those countries that still want to industrialise, they are going to want resources as well.

Nat: It is good for us but won't be for our children. I reckon my life will be easier, but my kids will be buggered.

Within this general view there were some subtle differences; for the disadvantaged there was environmental concern, but those better off were more concerned.

The well-educated middle class students were particularly angry, passionate and frustrated by the situation, especially the inaction by governments and business. The more privileged and wealthy shared similar views, but seemed to have a more cynical, even fatalistic attitude. These young people were genuinely concerned about environmental issues, and quite often were already doing things to minimise their footprint. But they felt largely powerless to do anything political.

As with the adult interviewees, they saw little point in becoming politically involved to stave off impending catastrophe:

Mel: Yeah, the whole world is going to self destruct. I just hope that we are not part of it when it happens [laughter]. 
Nell: If I could do something I would, but I have no money to contribute...

Mel: And we're 17 year-old school students...

Nell: No one's going to listen to us...

Mel: And if we protest it's like, 'oh, those crazy teenagers' [laughs].

Nell: Protesting doesn't work, it doesn’t do anything.

There was a lot of cynicism about the political process and any chance of successful intervention to rescue the environment:

Andy: Everything you need to do to fix the environment is either going to cost you billions and take you all your life to get there and by the time you get there you will find out that somebody else has a patent on it and you can't do it anyway.

One of the most interesting twists is the mismatch between expectations of apocalypse as far as the environmental future is concerned and relatively optimistic views of their own personal futures. Responses to the survey and focus group questions about their ambitions and their perceptions of the chances of achieving them revealed the young people had mostly positive views about their future and individual lives. In a large minority of the sample, there was even a trajectory of life achievements mapped out in advance.

In none of their accounts of the future was there any sense that the environmental apocalypse they also predict could have any impact on their choices, their later lives or intentions to raise a family. The possibility that the next 20 or 30 years could see increasing problems from climate change and oil shortage, or the impact of a wide ranging program of structural environmental reform does not figure at all in these personal ambitions. A frequent tag ending to these discussions declares that they hope the environment will be alright in their own lifetime but the future beyond that looks bleak.

The two-track thinking that is revealed in these interviews is as worrying from the point of view of collapse as the soft support for political intervention revealed by the opinion surveys. We suggest that no amount of extra information about climate change is going to make a dent in people's unwillingness to take drastic political action. Instead, this new information will be merely filed away where apocalyptic visions reside, making little impact on life planning or political choices.

\section{Business leaders and climate change}

Bowden's (2009) research on business leaders' views on climate change reveals a different pattern of understanding. They are remarkably positive about the future:

Frank: I'm normally very positive about things so I have to say that I always believe that the big sensibility will come up and people will find the light at the end of the tunnel and move in one direction that will make sense ... We must believe that something better will happen.

Paul: I'm very positive about the future and ... You know, we often lament - our home we built - we were not allowed to put in our water tank. That's only 15 years ago ... So I'm just trying to say that over a short time frame there has been a great change in some people's minds of what can occur. 
Some are decidedly less concerned about climate change in particular:

Interviewer: Do you worry?

John: Ohhhh ... Oh a bit yeah I s'pose. Got plenty of things to worry about so ...

Interviewer: So what do you think, do you sort of worry about climate change as an issue or $(\mathrm{mmm})$ ?

Peter: No. No. Nope. Not personally. Sorry.

The context was the development of the Labor government's Carbon Pollution Reduction Scheme (CPRS). This was a small-scale sample of ten business leaders and it cannot be considered representative. Yet it provides useful insight into the different perspectives on the future and environmental degradation. Like a number of participants in Threadgold's (2009) study, these business leaders seem confident that they themselves will not be affected by climate change. Unlike the young people, however, these interviewees had a clear economic interest in talking up the future. The majority were representatives of stakeholder industries in the climate change debate: coal mining and exports, shipping, aluminium and aviation, consultancy, business advocacy, technology and science and natural resources. Surprisingly given the supposedly bi-partisan recognition of climate change at the time of the interviews - a number seemed to believe that climate change is not as serious as posited (Bowden 2009). This is combined with a prioritisation of materialism and economic growth over alleviating climate change.

Participants suggested that the growth economy and capitalism are both inevitable and necessary for any kind of social order. The elder Bush's famous 1992 statement: 'The American way of life is not negotiable' is a good summary of their viewpoint. Many business leaders explained that the effect of the CPRS would be to make their industry uncompetitive - their business would merely migrate to a country where there was no such scheme in place. Consequently, they had to oppose the application of the scheme to their business. They argued that internationally and locally, economic growth would continue to require coal as a cheap energy source:

Amanda: international energy demand is growing at such a rate that coal will still be required for decades to come - low cost abundant energy is what you're looking for, so there's no doubt I think in our mind that coal will remain an important part of the global energy mix.

Paul: If we're wanting to replace baseload by the coal - or nuclear - with true renewables - to actually replace, the growth of that needs to be exponential. Because we just can't catch up with what's required ... We actually don't have a viable alternative.

To call a halt to growth would invite the end of all social order:

Paul: We will have social anarchy if we implement the environmental call to stop coal.

It was unthinkable that any such development could actually take place:

Peter: Oh, I - to be honest I - I don't worry about that at all because it won't, that won't happen. It's just not going to happen. Those mines up there they represent just way too much economically for our region for anybody to, to do away with them. It won't happen. It won't, it can't. 
10 T. Leahy et al.

Environmentalists who believed otherwise did not have a firm grip on reality:

Julie: People are living in la la land if they think [coal's] going to be gone overnight.

In this perspective the growth economy and competitive global capitalism is inevitable and anything else is fantastic and may result in the dissolution of all social order. If the crisis of climate change cannot be solved within that framework, it cannot be solved at all.

Taken together, Hunter residents accept the inevitability of the capitalist growth economy. No alternative is possible and nothing could be achieved by anyone who tried to stop it. The business leaders also exhibit elements of the cognitive dissonance described by Hamilton (2010, p. 95-98) that is common to deniers with vested interests. In all three sets of data there is a blockage to seeing anything other than the continuation of the capitalist growth economy, at least insofar as personal life and daily decision-making are concerned.

\section{The social dynamics of collapse}

Apocalyptic thinking has been a long-standing subtext in human history since preChristian times. A key qualitative difference today is that the prediction of 'apocalypse' is grounded in 'rationality' rather than 'spirituality' (Hulme 2008, Beddoe et al. 2009, Huesemann and Huesemann 2008).

The key question is posed by Tainter $(1988$, p. 50$)$ in relation to collapse as a repeated phenomenon of history: how can a collapse take place in a complex society where the whole administrative apparatus is set up to monitor and control the economy and take note of changes that threaten the flow of wealth? We will outline a theory that seems to work here. One account of collapse described by Tainter is the 'notion that fundamental limitations of social, political, and economic systems prevent an appropriate response to circumstances and this makes collapse inevitable'; 'successful complex societies become locked into their adaptations' (Tainter 1988, p. 54, 56), something which Dennis and Urry (2009, p. 56) refer to as 'path dependency' within the context of complexity theory. More broadly, class societies are characterized by what Durkheim called 'organic solidarity' - the parts of the society are interlocked as a social organism or social machine. The people who operate the parts of such social machines are located within roles that fit the machine's functioning. Even the ruling class cannot readily operate outside this framework (Perlman 1983).

Collapse can come from this automatism. The social machine of capitalism (competitive private ownership, wage labour, the growth economy) is serviced by its human parts. It has functioned in this manner so far but can also collapse if it cannot make appropriate changes in a new situation - like a car engine that works well when the car is on the road but seizes up when the car is driven into a lake. The detailed content for this analysis is the understanding of the roots of the current environmental crisis from the perspective of political economy. In capitalism, firms compete to make profits or are abandoned by their shareholders. Technological efficiency gives a competitive edge and produces growth as the outcome. Every individual company and nation is economically compelled to externalize the costs of environmental side effects in order to stay in the capitalist game. Workers are also consumers, voters and, 
through their superannuation, shareholders. Because capitalism requires that people have employment to live adequately, the public are motivated to vote for parties that increase growth and maintain employment levels. As workers whose daily lives are dominated by hierarchical work discipline, citizens cherish their increasing remuneration and its associated consumer spending as compensation for their "alienated labour". That makes them unlikely allies for any kind of environmentalist plan that might threaten jobs, raise taxes or reduce consumer spending, all of which seem certain to be necessary to restructure energy and transport to avoid global warming - at least if we are intending to make these changes within the context of a capitalist economy (McLaughlin 1993, Trainer 1995, 2007, Coates and Leahy 2006, Kovel 2007, Baer 2008, Foster 2009). According to political economy, the error of "Ecological Modernisation" theory is that it envisages the voluntaristic suspension of one aspect of this social machine - the externalization of environmental costs - while other aspects of the social machine that produce this effect stay in place - for example competitive private ownership and alienated labour. Within our analysis, Ecological Modernisation is a theory of what might ideally happen, but the pattern of events so far suggests the greater relevance of another view.

The premise of this analysis is not that individuals behave in a patterned way because of an overwhelming determination of action by society. Once the social game of a particular mode of production has been set up, people generally make choices that they believe will serve their interests, broadly speaking. These choices may be to pursue autonomy, regard, affection, bodily wellbeing, creative expression and the like. However these choices are constrained by what is taken for granted - the inevitability and necessity of the social game in question. The particular efficacy of modes of production in perpetuating themselves as machines is to set people up as social groups whose relationship with other groups is an aspect the social game. As people in groups go about "serving their own interests", they also maintain the functioning of the social machine as a whole. The game, once it has been set up, locks people into a set of options which ensure the overall maintenance of the game itself. What this also suggests is that class society itself, and its various modes of production, are invented as social games (Clastres 1987) or as discourses (Foucault 1979, 1980) which set up these machine functions and which go on to trap people in those frameworks (Mann 1986). Castoriadis (1987) strengthens this analysis by arguing that each social order or mode of production is held together by a 'social imaginary' which becomes unconscious. This mode of thought is based on a set of fictions, which become real if society operates by them. People forget human beings have imagined them, and often feel powerless to intervene.

\section{Conclusion}

These thoughts on the theory of collapse are intended to make sense of a situation in which most indicators - namely the public opinion data, the scientific statement of the problem, the explanation of the difficulties of transition, the poor political response - point to collapse as the most likely outcome. Our own interview and survey data demonstrates that people can expect a collapse and yet have no intention to change their conduct to prevent it. It is thus further evidence of the likelihood of collapse.

The theory of collapse also gives us a way to understand the two-track thinking that we find in our interviews with the public, as well as the resistance to change we 
find among business leaders. In our interview data, one of the most common responses and explanations of failure to act is that 'as one person on your own' one cannot accomplish anything. Business leaders state as a fact that they cannot do anything that might compromise their company's position in the global market, and that anything outside of the growth economy must represent the end of all social order. Such comments acknowledge and reveal the participation of individuals in the social machine and their sense of entrapment within it.

In our interview data, we see a gap between two tracks of thinking. One track is rational understanding of the danger of apocalypse. On the other track is the social imaginary of capitalism as it normalises daily life decisions within the capitalist growth machine. You must have a job and will vote accordingly. You are just one person and cannot make any meaningful intervention in society. You have worked hard and can expect to be rewarded, with consumer goods, an affluent future followed by a comfortable retirement. Your company must compete on the global market and you will lobby accordingly. No drastic change to current economic arrangements is conceivable or possible. The social imaginary of this current order makes it very difficult to envisage the major changes that would actually be necessary to deal with current problems.

Our intention here has been to realistically evaluate the situation we are now in. Much social science on this topic has a kind of 'boy scout' willingness to tell us how it can all be fixed. Giddens and Beck declare that the business class can change its spots. Beck has a better idea of the drastic nature of the change that may be involved but rules out the possibility of collapse. The only place in World at Risk where Beck considers an end to civilisation as a possible outcome is a somewhat oblique discussion: when people speak of the 'end of the world' they forget that this apocalyptic vision has been current several times in European history; speaking of the end of the world implies 'our own inability to recognize the signs of new world beginnings' (Beck 2009, p. 219). In other words, we are seeing the birth of the new world risk society with the characteristics he describes. Unfortunately, Beck here gives us a philosophical answer - 'there is always something new' - to an empirical social science question - 'what is the shape of the future?'.

We do not offer any suggestions as to what might be politically appropriate if our prognosis is correct. A realistic analysis of the current conjuncture is surely the necessary first step for an adequate response. We do not believe collapse is an inevitable outcome; we merely argue that the evidence at the moment points to it as the most likely outcome and that social scientists should get to grips with this current reality. If climate change and collapse is forestalled, it will be the outcome of agency and imaginative invention on the part of individuals and groups of people who are not behaving as automatons within the social machine of capitalism.

\section{References}

Atkinson, A., 2007. 'Cities after oil 1: sustainable development' and energy Futures. City, 11 (2), 201-213.

Baer, H., 2008. Global warming as a by-product of the capitalist treadmill of production and consumption: the need for an alternative global system. The Australian Journal of Anthropology, 19 (1), 1-4.

Beck, U., 2009. World at risk. Cambridge: Polity Press.

Beckman, L. and Page, E.A., 2008. Perspectives on justice, democracy and global climate change. Environmental Politics, 17 (4), 527-535. 
Beddoe, R. et al. 2009. Overcoming systemic roadblocks to sustainability: the evolutionary redesign of worldviews, institutions, and technologies. Proceedings of the National Academy of Sciences, 106(8),2843-2489.

Blühdorn, I., 2007. Sustaining the unsustainable: symbolic politics and the politics of simulation. Environmental Politics, 16 (2), 251-275 .

Bowden, V., 2009. Uncertainty in a coal-dependent region: how business leaders in the Hunter are responding to climate change. Thesis (Hons). University of Newcastle, Australia.

Caldicott, H. 2006. Nuclear Power is Not the Answer to Global Warming or Anything Else. Carlton: Melbourne University Press.

Carolan, M. 2010. Sociological ambivalence and climate change. Local Environment, 15(4),309-321.

Carroll, P., Casswell, S., Huakau, J., Perry, P. and Chapman, P.H., 2009.

Environmental attitudes, beliefs about social justice and intention to vote Green: lessons for the New Zealand Green Party? Environmental Politics, 18 (2), 257278.

Castoriadis, C., 1987. The imaginary institution of society. Cambridge: Polity Press.

Caney, S., 2008. Human rights, climate change, and discounting. Environmental Politics, 17 (4), 536-555.

Change and Development, 2009, Special issue on 'Capitalism and Climate Change' 40, (1).

Clastres, P., 1987. Society against the state: essays in political anthropology. New York: Zone Books.

Coates, J. and Leahy T., 2006. Ideology and politics: essential factors in the path towards sustainability. Electronic Green Journal [online], 23 (Spring).

Available from: http://egj.lib.uidaho.edu/egj23/coates1.html [Accessed 23 July 2008].

Cohen, M. 2010. Destination unknown: pursuing sustainable mobility in the face of rival societal aspirations. Research Policy 39, 459-470.

Compston, H., 2009. Networks, resources, political strategy and climate policy. Environmental Politics, 18 (5), 727-746.

Curran, G., 2009. Ecological modernisation and climate change in Australia. Environmental Politics, 18 (2), 201-217.

Dennis, K., and Urry, J., 2009. After the car. Cambridge: Polity Press.

Diamond, J., 2005. Collapse: how societies choose to fail or survive. Camberwell, Victoria: Penguin.

Dyer, G., 2008. Climate Wars. Melbourne: Scribe.

Foucault, M., 1979. Discipline and punish: the birth of the prison. London: Penguin.

Foucault, M., 1980. The history of sexuality, volume 1: an introduction. New York: Vintage.

Foster, J. B. 2000. The ecological revolution: making peace with the planet. New York: Monthly Review Press.

Garrett, G. and Jackman, S., 2009, In this climate Australians lead, Americans lag behind. Sydney Morning Herald, 21 November, p. 7.

Giddens, A., 2009. The politics of climate change. London: Polity Press.

Gow, J. and Leahy, T., 2005. Apocalypse probably: agency and environmental risk in the Hunter region. Journal of Sociology, 41 (2), 1-25.

Grundig, F., 2009. Political strategy and climate policy: a rational choice perspective. Environmental Politics, 18 (5), 747-764.

Hamilton, C., 2010. Requiem for a species: why we resist the truth about climate 
14 T. Leahy et al.

change. Crows Nest, Australia: Allen and Unwin.

Hansen, J. et al., 2008. Target atmospheric CO2: where should humanity aim?

[online]. Available from: http://www.columbia.edu/<jeh1/ [accessed 23 March 2009].

Hanson, F., 2009. The Lowy Institute poll 2009: Australia and the world, public opinion and foreign policy. Canberra: Lowy Institute for Public Policy.

Heinberg, R., 2003. The Party's over: oil, war and the fate of industrial societies.

New York: Clairview.

Huesemann, M. and J. Huesemann. 2008. Will progress in science and technology avert or accelerate global collapse? A critical analysis and policy recommendations. Environment, Development, and Sustainability, 10 (6), 787825.

Hulme, M. 2008. The conquering of climate: discourses of fear and their dissolution. Geographical Journal, 174(1), 5-16.

Hughes, E. 2007. Dissolving the Nation: Self-Deception and Symbolic Inversion in the GM Debate. Environmental Politics, 16 (2), 318-336.

IPCC, 2007. Climate change 2007: synthesis report [online]. Available from: http://www.ipc.ch/pdf/assessment-report/. [Accessed 30 June 2009].

Kamminga, M.R., 2008. The ethics of climate politics: four modes of moral discourse. Environmental Politics, 17 (4), 673-692.

Kovel, J., 2007. The enemy of nature: the end of capitalism or the end of the world? London: Zed.

Krosnick, J. A., 2010. Global warming poll: Selected results, Stanford University [online]. Available from: http://woods.stanford.edu/docs/surveys/GlobalWarming-Survey-Selected-Results-June2010.pdf. [Accessed 13 July 2010].

Kunstler, J.H., 2005. The long emergency: surviving the end of oil. Climate change, and other converging catastrophes of the twenty-first century. New York: Grove Press.

Layfield, D. 2008. New politics or environmental class struggle? Environmental Politics, 17 (1), 3-19.

Leahy, T., 2003. Ecofeminism in theory and practice: women's responses to environmental issues. Journal of Interdisciplinary Gender Studies, 7(1 \& 2), 106-125.

Lever-Tracy, C., 2008. Global warming and sociology. Current Sociology 56 (3), 445-466.

Levi, M.A., 2009. Assessing China’s Carbon-Cutting Proposal. Council on Foreign Relations [online], 29 November 2009. Available from: http://www.cfr.org/publication/20862. [Accessed 28 May 2010].

Li, M., 2009. Capitalism, climate change and the transition to sustainability: alternative scenarios for the US, China and the World. Development and Change, 40 (6), 1039-1061.

Lowe, I. 2007. Reaction Time: Climate Change and the Nuclear Option. Quarterly Essay, 27.

Lynas, M., 2007. Six degrees: our future on a hotter planet. London: Harper Perennial.

MacKay, D. 2009. Sustainable Energy - Without the Hot Air. Cambridge: UIT.

Mann, M.,1986. The sources of social power: volume 1; a history of power from the beginning to A.D. 1760, Cambridge University Press.

Maslin, M. 2009. Global warming: A very short introduction. Oxford: Oxford University Press. 
McLaughlin, A., 1993. Regarding nature: industrialism and deep ecology. Albany: State University of New York.

McCright, A.M. and R.R. Dunlap 2010. Anti-Reflexivity: The American Conservative Movement's Success in Undermining Climate Science and Policy. Theory, Culture and Society, 27 (2-3), 100-133.

Mol, A.P. and Spaargaren, G., 2000. Ecological modernisation theory in debate: a review. Environmental Politics, 9 (2), 17-49.

Newcastle Port Corporation (2010) The port of Newcastle. [online], Available from: http://www.newportcorp.com/site/index.cfm?display=111627. [Accessed 27 May 2010].

Norgaard, K. M., 2006. 'We don’t really want to know': environmental justice and socially organized denial of global warming in Norway'. Organization and Environment, 19 (3), 347-370.

O’Connor, J. 1999. A prolegomena to an ecological marxism: thoughts on the materialist conception of history. Capitalism, Nature and Socialism, 10 (2), 77107.

Page, E., 2008. Distributing the burdens of climate change. Environmental Politics, 17 (4), 556-575.

Pearse, G, 2009. Quarry Vision: Coal, Climate Change and the End of the Resources Boom. Quarterly Essay 33.

Pepper, D. 1993. Eco-socialism: from deep ecology to social justice. New York: Routledge.

Perlman, F., 1983. Against his-story, against Leviathan! Detroit, Michigan: Black and Red.

Pfeiffer, D.A., 2006. Eating fossil fuels: oil, food and the coming crisis in agriculture. Toronto, Canada: New Society Publishers.

Pietsch, J. and McAllister, I., 2010. 'A diabolical challenge': public opinion and climate change policy in Australia. Environmental Politics, 19 (2), 217-236.

Raupach, M.R., Marland, G., Ciais, P., Le Quere, C., Canadell, J.G., Klepper, G. and Field C.B., 2007. Global and regional drivers of accelerating CO2 emissions. Proceedings of the National Academy of Sciences of the United States of America, 104 (24), 10288-10293.

Rogelj, J. et al., 2010. Copenhagen accord pledges are paltry. Nature, 464, 11261128.

Romm, J., 2009. Will Europe go for a 30\% cut in carbon pollution (from 1990 levels) by 2020 at Copenhagen? The Energy Collective [online], 12 September 2009. Available from: http://theenergycollective.com/cop15/53149. [Accessed 28 May 2010].

Rootes, C., 2008. The first climate change election? The Australian general election of 24 November 2007. Environmental Politics, 17 (3) 473-480.

Saad, L., 2009. Increased Number Think Global Warming is Exaggerated, Gallup Inc [online], Available from: http://www.gallup.com/poll/116590/ [Accessed 9 July 2010].

Spence, A., Venables, D., Pidgeon, N., Poortinga, W. and Demski, C., 2010. Public perception of climate change and energy futures in Britain: Summary findings of a survey conducted in January-March 2010. Cardiff, School of Psychology [online]. Available from:

http://www.cf.ac.uk/psych/home2/docs/UnderstandingRiskFinalReport.pdf [Accessed 9 July 2010]. 
16 T. Leahy et al.

Spratt, D. and Sutton, P., 2008. Climate code red: the case for emergency action. Melbourne: Scribe.

Stoll-Kleemann, S. O’Riordan, T and Jaeger, C. 2001. The psychology of denial concerning climate mitigation measures: evidence from Swiss focus groups. Global Environmental Change, 11(2),107-117.

Tainter, J.E., 1988. The collapse of complex societies. Cambridge University Press. Theory, Culture and Society 2010, Special issue on 'Changing Climates', 27, (2/3).

Threadgold, S., 2009. Youth and habitus at three Australian schools: perceptions of ambitions, risks and the future in reflexive modernity. Thesis (PhD). University of Newcastle, Australia.

Trainer, T., 1995. The conserver society: alternatives for sustainability. London: Zed Books.

Trainer, T., 2007. Renewable energy cannot sustain a consumer society. Dordrecht: Springer.

UNFCC 2009. United Nations framework convention on climate change [online]. Available from: http://unfcc.int/resource/docs/2009/cop15/eng/107.pdf. [Accessed 2 May 2010].

Urry, J. 2005. The complexity turn. Theory, Culture \& Society, 22 (1), 1-14.

Urry, J. 2008. Climate change, travel and complex futures. The British Journal of Sociology, 59 (2) 261-279.

Urry, J. 2010. Sociology and climate change. The Sociological Review, 57 (0), 84100.

van der Heijden, H. A., 2008. Green governmentality, ecological modernisation or civic environmentalism? Dealing with global environmental problems. Environmental Politics, 17 (5), 835-839.

Walker, G. and E. Shove. 2007. Ambivalence, sustainability, and the governance of socio-technical transitions. Journal of Environmental Policy and Planning 9 (34), 213-225. 